\title{
REDUPLICATION OF VERB IN MUNA LANGUAGE
}

\author{
By: \\ ADERLAEPE \\ A Teaching Staff on English Study Program Faculty of Education UHO Kendari \\ Email: aderlaepe@uho.ac.id
}

\begin{abstract}
This research aims at describing the types and functions of verb reduplication in Muna language. Problems of the research are: (1) what types of verb reduplication in Muna language? (2) what are the functions of reduplication found on verb in Muna language? Data of the research were taken by using the techniques of noting, translation, introspection, and elicitation. The achieved data were analyzed by following the steps: (1) made the classification, (2) determine the basic element (stem) of every reduplication, (3) pay attention to the process of reduplication, (4) and determine the function of reduplication occur on verbs.

Results of the research are as follows:

1. There are three types of verb reduplication in Muna language, namely: full, partial, and affixed reduplications. Partial reduplication of verb in Muna language consists of regressive and progressive reduplications. In affixed reduplicaton, the kinds of affixes role in the reduplication process are: suffix - I which presents in the forms of suffix $-p i$, $-n i$, -li, and $-m i$; prefix sa-; and confix po-li.

2. Full reduplication on verb in Muna language functions to state repeatitive activity and relax condition or activity done to relax. On the other hand, partial reduplication in the form of regressive reduplication functions to state repeatitive and serious activities, whereas the progressive one states reciprocal activity done by people in group. The last one, affixed reduplication that attached by suffix -pi, - $l i$, and $-m i$ states repeatitive and suffix $-n i$ states an activity done seriously. Reduplication with prefix $s a$ - states frequentive activity and the reduplication attached by confix po-li that states reciprocality and repeatitive activity.
\end{abstract}

Key Words: Reduplication, Verb, Affix, Morphological Process, And Muna Language

\section{INTRODUCTION}

Muna language is the only one of local language used by people as a vernacular in daily social interaction by people of Munanese. The origin of the people live in Muna regency, the province of South East Sulawesi.

Muna language consists of several dialects. Berg (1989) states that Muna language has three dialects, they are South, Tiworo, and Standard dialect. South dialect is used at by the people at southern part of Muna island particularly at $\mathrm{Gu}$ and Mawasangka areas, also at Siompu and Kadatua islands. Administratively, $\mathrm{Gu}$ and Mawasangka are sub districts of Buton Tengah regency, whereas Siompu and Kadatua are the territory of Buton regency. Tiworo dialect is used at Tiworo (north western part of Muna island) which scopes Kambaara and surrounding area include Balu and 
Maginti small islands. The last one is Standard dialect, the areas of this one extents from the Middle part, Eastern, Western, and Northern of Muna island.

Verb in Muna language can not stand alone. It must be completed by subject. This phenomenon is a characteristic as a morphosyntax language. As an agglutinative language, verb reduplication process can occur more than once. In this case, the results of reduplication process can be a stem of the next reduplication. Verb kala 'go' for example, firstly full reduplication occurs becomes kala-kala 'go for a walk'. Secondly, on the derived word kala-kala 'go for a walk' can occur affixation, in this case suffix -ha attaches to the end of the construction; so the new derived word is kala-kalaha 'time to go for a walk'. Thirdly, on the construction of kalakalaha 'time to go for a walk' can occur prefixation where prefix $-k a$ attaches at the beginning of the construction. The new derived word now is kakala-kalaha 'the place to go for a walk'. This phenomenon is a proof that reduplication of verb in Muna language is a multiphase since it can happen more than once, can be twice or three times. This phenomenon makes the writer interesting to take research concerning verb reduplication system in Muna language with two main problems as follows: (1) what types of verb reduplication are found in Muna language? (2) what are the functions of reduplication found on verb in Muna language? Based on these problems, objectives of the research are (1) to describe the types of verb reduplication in Muna language and (2) to describe the functions of reduplication found on verb in Muna language.

\section{THEORETICAL REVIEW}

Adopted theories of reduplication are stated by Nida (1962), Quirk (1989), Kridalaksana (1984), Verhaar (1999), and Parera (1994), also Samsuri (1991) According to Nida (1962 : 84), reduplication is a comprehensive repeating or partial of the root or stem. A form of stem that is repeated overall can be seen in Tojolabal language: $O c$ 'come in' becomes ococ 'slowly come in'. In some root forms, we can find three times repeating of reduplication, such in San Blas language used in Panama: mu.a 'move' becomes mu.a mu.a 'continously move' and becomes ти. а ти.а ти.a 'move strongly and continously'. These words are used to describe the movement of wave in the sea.

Quirk (1989: 1029) categoryzes the reduplication as compound form. His argument can be caused by the lack of reduplication phenomena in English. According to him, compound form has two or more elements which is quite identic or different to the basic form of word. As example, goody-goody is different from goody. On the other hand, the form criss-cross is quite identic to cross.

Kridalaksana (1984:167) gives the definition of reduplication as the process and the result of repeating in language unit as the phonological and grammatical devices. Furtherly, he argues that in the case of reduplication process, usually the repeated element is the basic morpheme. Sometimes the repeated element is the syllable of the basic morpheme. As example in Indonesian language: tama in pertama-tama 'firstly'. 
Kridalaksana classifies the reduplication of Indonesia language into three groups, namely phonologic, morphemic, and syntactic reduplications. Phonologic and syntactic reduplications are not discussed further by Kridalaksana because both fields exist beyond the morphologic scope.

Verhaar (1999:152) states that various languages in the world own the reduplication. Some of them are universal, but the others are unique. The unique one principally violates the general morphological principle that had been formulated by some linguists. This phenomenon can be found in Kola language that used by people in South Eastern of Maluku.

Parera (1994: 49) does not use the term of reduplication, but repeat form. According to him, the repeat form is a morphological process that always consist of two or more morphemes. Kuda-kuda 'horses' in bahasa Indonesia for example, consist of two morphemes: kuda 'horse' as first morpheme and its repeating as the second one. Sayurmayur 'vegetables' in Indonesian language consist of sayur as one morpheme and mayur as the other one. Parera then asserts that there is a difference between reduplication and repetition. In the form of repetition, the constituents exist in independence autonomy. Such form usually appears in the lyrics of songs or poetry.

Samsuri (1994:191) defines the reduplication as a repeating form. It is a morphological process that can be found in some languages in the world. He classifies the reduplication into two parts, full and partial reduplication. Full reduplication is the phenomenon of language useage where the basic word is repeated totally, but the partial one is the oppose to the full one. The partial reduplication is the partially repeating of word. He gives examples in Indonesian language: lihat - lihat 'have a look' is a full reduplication and bermain-main 'play' is the partial one.

Theories of verb, the writer adopts Hornby's (1995), Frank's 91972), Alwi's et al. (2000), and Jacob's (1995). According to Hornby (1995: 1323), verb is a word or phrase indicating an action, an event or a state, example: take, eat, walk. Meanwhile, Frank (1972: 47) gives the explanation about verb as the most complex part of speech. Its varying arrangement with noun determine the different kinds of sentences: statement, question, command, exclamations.

Alwi, et al. (2000: 87) states that generally verb can be identified by another word class, especially adjective because it is modified by adjective besides the characteristics of verb can be well recognized by paying attention to morphological, syntactical, and semantical behaviours. Verb has the main function as the predicate in a sentence although it can also fills another function.

Jacobs (1995:10) asserts that verb is the most important element of sentence. In some cases, the types of a verb, transitive or intransitive, enfluences the presence of other elements of a sentence. In the sentence which uses two valencies - verb, there must be two arguments or participants, they are may be subject and object. The argument in this case is always filled by noun or noun phrase. Accordingly if the three valencies-verb fills the predicate of the sentence, absolutely the other element which present are three; 
they may be subject, object, and complement; or can be consist of subject, and direct and indirect object. The verb like buy is two valencies verb. When it presents in the sentence, the object of sentence must present, otherwise the sentence is not complete.

\section{METHODOLOGY}

The employed method of this research is a descriptive qualitative. It is used to describe a number of variables related to the elements of discussion. The object is the natural usage of Muna language in daily communication specificly the grammatical system of verb reduplication.

Source of data was oral language, in this case Muna language used by Munanese people in Munanese community. Data of the research were taken by using techniques of (1) noting, (2) elicitation, (3) introspection, and (4) translation. In analyzing the data, the writer uses Immediate Constituent Analysis to pay attention process as well as the function of reduplication occurs on verb in Muna language.

\section{FINDING AND DISCUSSION}

Reduplication of verb in Muna language principally is a phenomenon of morphological process where the relationship between root/stem and a new construction can be seen empirically. It is a structural reduplication that can be classified into (1) full, (2) partial, and (3) affixed reduplication.

\section{Full Reduplication}

Full reduplication is a kind of reduplication where the constituent of basic morpheme simultaneously reduplicated. Viewed from physical element, the structure of full reduplication consists of two constituents: one is a stem and another one is a reduplicated form. The constituent of stem is basically an original/basic morpheme which becomes the basic construction of reduplication, whereas the reduplicated form is the additional construction which is produced by the process of reduplication. Syntacticly, the twomorphemes in full reduplication is treated as one element/unity.

Semanticly, the full reduplication of verb states two situation of meaning, namely repeatitive activity and relax situation. It means that verb reduplication process in full reduplication functions as the repeatitive marker and relaxity marker. Pay attention to these examples:

$$
\begin{aligned}
& \text { a. lengka 'open' }+\mathrm{R} \longrightarrow \\
& \text { lengka - lengka 'open repeatedly' } \\
& \text { b. soba 'try' }+\mathrm{R} \longrightarrow \\
& \text { soba - soba 'try repeatedly' } \\
& \text { c. ghondo 'look' }+\mathrm{R} \longrightarrow \\
& \text { ghondo-ghondo 'look } \\
& \text { repeatedly' }
\end{aligned}
$$

The full reduplication of lengkalengka open repeatedly', soba-soba 'try repeatedly', and ghondo-ghondo 'look repeatedly' in the examples above are formed through reduplication process. The morphemes of lengka 'open', soba 'try', and ghondo 'look' are reduplicated simultaneously and the results are the full reduplications of lengka-lengka, soba-sobe, and ghondoghondo. Structurally the constituent of lengka consists of one morpheme only, but the constituent of full reduplication lengka-lengka consists of two morphemes. This phenomenon also occurs on soba and ghondo which each 
of them consists of one single morpheme, but soba-soba consists of two morphemes and ghondo-ghondo as well. In the constructions of lengkalengka 'open repeatedly', the basic morpheme as the stem is lengka on the left side; whereas the additional one as the reduplicated form is lengka on the right side. The same case also occurs in soba-sobe, the stem is soba on the left side and the reduplicated form is soba on the right side. The constituent of ghondo-ghondo is the same, where the stem is ghondo on the left side and the reduplicated form is ghondo on the right side. Syntacticly, the full reduplications of lengka-lengka,soba-soba, and ghondo-ghondo are treated as one element. Example:

Lengka-lengka boku aitu!

Open - R book that

"Open that book repeatedly "

Full reduplication of lengkalengka in the sentence above expresses the activity of lengka 'open' more than once and done repeatedly.

\section{Partial Reduplication}

Partial reduplication can be distinguished from the full one by paying attention to the basic element. If we repeat only a part of basic element of the word, it is partial reduplication; but when we repeat all part of basic element comprehensively, it is the full one. The writer adopts Simatupang's theory (1983) to classify partial reduplication into regressive and progressive reduplications.

Regressive reduplication is a kind of partial reduplication where the repeated part of the basic element is on the left side. Contrarily, progressive reduplication is a kind of partial reduplication where the repeated part of the basic element is on the right side. Both of these reduplications are described in the following discussion.

\section{Regressive Reduplication}

Structurally, the contituent of regressive reduplication starts with repeated element. Accordingly, it seems that the process of reduplication towards the left side. Examples:

a. antagi 'wait' $+\mathrm{R} \longrightarrow$ antaantagi 'wait seriously'

b. kapihi 'look for' $+\mathrm{R} \longrightarrow$ kapikapihi 'look for seriously'

c. fekiri 'think' $+\mathrm{R} \longrightarrow$ fekifekiri 'think seriously'

Data of regressive reduplication above, anta-antagi is derived from basic element (stem) of antagi 'wait'. The repeated part is anta. It lies on the left side in the basic element antagi. The same thing occurs to kapi-kapihi with the basic element is kapihi 'look for' and the repeated part is kapi. The position of kapi in the construction of kapihi is obviously on the left side. Next, feki-fekiri is derived from the basic element fekiri 'think' with the repeated element is feki that locates at the left side of the construction fekiri.

Reduplication process in the regressive reduplication above enfluences the changing of meaning. The stem of kapihi 'look for' becomes kapi-kapihi 'think seriusly'; antagi 'wait' becomes anta-antagi 'wait seriously' ; and fekiri 'think' becoms feki-fekiri 'think seriously'. Certainly the regressive reduplication in this case functions to state serious activity. Therefore, reduplication of regressive one in this phenomenon means the 
activity done seriously. Pay attention to the sentences bellow:

Ina-ku neanta-antagi measono kenta

mother-my $3 ; \mathrm{S}$ wait $-\mathrm{R}$ sell who

fish

" My mother wait the fish seller seriously “"

\section{Progressive Reduplication}

Progressive reduplication is the opposite of the regressive one. Structurally, the contituent of progressive reduplication starts with repeated element. It seems that the process of this kind of reduplication towards the right side. Examples:

a. posepa 'kick each other' $+\mathrm{R} \longrightarrow$ posepa-sepa 'kick among other'

b. popongko 'kill each other' $+\mathrm{R} \longrightarrow$ popongko-pongko 'kill among other'

c. potemba 'shoot each other' $+\mathrm{R} \longrightarrow$ potemba-temba 'shoot among other'

Data of progressive reduplication above, posepa-sepa is derived from basic element (stem) of posepa 'kick each other'. The repeated part is sepa 'kick'. It lies on the right side in the basic element (stem) posepa. The same thing occurs to popongko-pongko with the basic element or stem is popongko 'kill each other', and the repeated part is pongko. The position of pongko in the construction of stem popongko is obviously on the right side. Then potemba-temba is derived from the basic element or stem of potemba 'shoot each other' with the repeated element is temba which locates at the right side of the construction potemba.

Reduplication process in the progressive reduplication above enfluences the changing of meaning. The stem of posepa 'kick each other' becomes posepa-sepa 'kick among other' ; popongko 'kill each other' becomes popongko-pongko 'kill among other'; and potemba 'shoot each other' becoms potemba-temba 'shoot among other'. So the progressive reduplication in this case functions to state the plurality. Therefore, reduplication of progressive one in this phenomenon means the activity done by people in group. Pay attention to the sentences bellow:

Pogoluno doposepa-sepa welo
lapanga
play ball 3:P kick - R inside
field
"foot ball players kick among other
in the field "

Progressive reduplication of doposepa-sepa 'kick among other' in the sentence above semanticly states that the people did the activity of posepa 'kick each other' not only two, but they are in group. In this case, each group more than one people.

\section{Affixed Reduplication}

Affixed reduplication is a kind of reduplication, that is attached by certain affix. The kind of affix found by the writer which attaches to the reduplication process are as follows:

\section{1. suffix $-I$}

Suffix $-I$ attaches to reduplication process of verb in Muna language can be in the forms of $-p i,-n i,-l i$, and $-m i$. Verb reduplication with suffix $-I$, has various form of suffix $-p i,-n i,-l i$, and mi. Examples:

$$
\begin{aligned}
& \text { hela 'pull' }+\mathrm{R} \longrightarrow \text { hela- } \\
& \text { helapi 'pull repeatedly' } \\
& \text { seli 'dig' }+\mathrm{R} \longrightarrow \text { seli-selipi } \\
& \text { 'dig repeatedly' }
\end{aligned}
$$


Verbs hela and seli in reduplication process above, the kind of sufffix that presents must be suffix -pi. In this case, suffix $-I$ in verbs of hela and seli presents in the form of -pi. Semanticly, reduplication process with suffix $-p i$ functions to state the activity done repeatedly. It means the activity of hela 'pull' and seli 'dig' is done more than once if becomes hela-helapi and seliselipi. Pay attention to the sentences bellow:

Hela-helapi katondo aitu!

Pull-R fence that

"Pull repeatedly that fence!"

Suffix $-I$ presents in the form of $-n i$ when attaches to the verb of dhaga 'take care'. The reduplication process is:

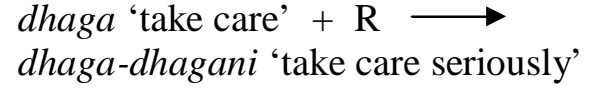

Suffix $-n i$ in this process functions to state the seriousness. Therefore, it means the activity done seriously. Examples:

Dhaga-dhagani anahi aitu

bhahita nokala te kabhongka!

take care $-\mathrm{R}$ child that might $3: \mathrm{s}$ go at road

" Take care that child, don't let him go to the road "

Suffix - I presents in the form of $l i$ if the verbs are tunu 'burn' ; sepa 'kick'; tisa 'plant'; and wogha 'hit'. Look the reduplication process bellow:
a. tипи 'burn' $+\mathrm{R} \longrightarrow$ tunu-tunuli
'burn repeatedly'
b. sepa 'kick' + $\mathrm{R} \longrightarrow$ sepa-sepali
'kick repeatedly'
c. tisa 'plant' $+\mathrm{R} \longrightarrow$ tisa-tisali
'plant repeatedly'

d. wogha 'hit' $+\mathrm{R} \longrightarrow$ wogha-

woghali 'hit repeatedly'

Suffix $-I$ in reduplication process of verb in Muna language becomes - $t i$ if the stems are horo 'jump'. See the reduplication process bellow:

horo 'jump $+\mathrm{R} \longrightarrow$ horo-

horomi 'jump repeatedly'

\section{Prefix sa-}

Prefix sa- that attaches to the reduplication of verb in Muna language functions to state frequentive activity. Pay attention to the process of reduplication bellow:

a. ngkora 'sit' $+\mathrm{R} \longrightarrow$ sangkorangkora 'often sit'

b. gau 'cook' $+\mathrm{R} \longrightarrow$ sagau-gau 'often cook'

c. fuma 'eat' $+\mathrm{R} \longrightarrow$ safumafuma 'often eat'

Reduplicatin of sangkora-ngkora above means the activity of ngkora 'sit' is done frequently. The same thing happens to sagau-gau means the activity of gau 'cook' is done frequently. Then, safuma-fuma means the activity of fuma 'eat' is done frequently. Pay attention to the sentences bellow:

La Oti sangkora-ngkora ne sepeda La Oti sit $-\mathrm{R}$ at bike "La Oti often sits on the bike " Andoa maitu sagau-gau mombakano They that cook-R delicious " They often cook delicious meal "

\section{Confix po-li}

Confix po-li that attaches to reduplication of verb in Muna language states reciprocal activity done repeatedly. So, it functions as a reciprocality and repeatitive marker. The process of reduplication with confix po-li can be seen bellow: 


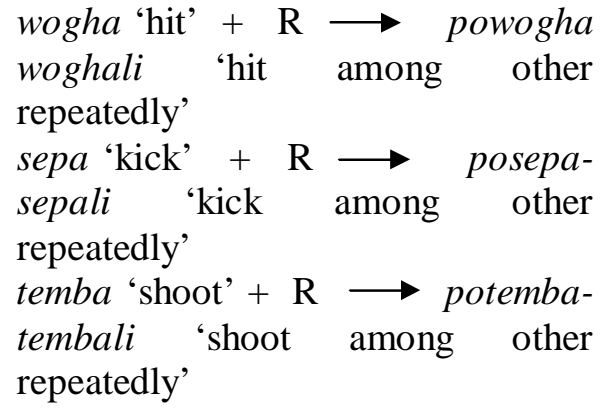

Reduplication of powogha-woghali above semanticly states the activity of wogha 'hit' is done by people in group reciprocally. This thing also happens to reduplication of posepa-sepali that means the activity of sepa 'kick' is done by people in group reciprocally. Then in potemba-tembali, the activity of temba 'shoot' is done by several people reciprocally. Examples:

\section{Mahasiswa UHO dopowogha-woghali student UHO 3:P hit - R \\ "UHO students hit among other repeatedly" \\ Pada dopogolu, doposepa-sepali}

After 3: P play foot ball 3:P kick - R

" After playing foot ball, they kick among other repeatedly “

Tantarahi te Ambo dopotembatembali

soldier Pl at Ambon 3:P shoot - R

"Soldiers at Ambon shoot among other repeatedly “

\section{CONCLUSIONS}

The writer takes the conclusion according to the finding and description about reduplication of verb in Muna language as follows:

1. Reduplication of verb in Muna language can be classified into three types, namely: (1) full reduplication; (2) partial reduplication; and (3) affixed reduplication. In full reduplication, the construction of verb is repeated simultaneously; whereas in partial reduplication, not all construction is repeated, but only a part. In affixed reduplication, a part of verb construction is repeated with certain affix. Partial reduplication of verb in Muna language consists of two kinds: regressive and progressive reduplications. In affixed reduplicaton, the kinds of affixes role in verb reduplication process are: suffix $-I$ which the variables of suffix $-p i,-n i$, $-l i$, and $-m i$; prefix $s a-;$ and confix po-li.

2. There are two functions found in full reduplication of verb in Muna language, they are: (1) repeatitive marker and (2) relaxive marker. Repeatitive marker means reduplication functions to state the activity done repeatedly; and relaxive marker means reduplication functions to state the activity done relaxly. In regressive reduplication, there are also two functions: (1) repeatitive marker (means the reduplication functions to state the meaning of activity done repeatedly) and (2) seriousness marker (means the reduplication states the meaning of activity done seriously). Progressive reduplication states plurality marker, it means the reduplication states the meaning of activity done be people in a group. The last one, affixes reduplication that attached by suffix - $i$, - $l i$, and $m i$ states repeatitive marker and suffix - $n i$ states seriousness marker. Reduplication with prefix $s a$ - states frequentive marker and reduplication attached by confix po$l i$ states reciprocality and repeatitive marker. 


\section{BIBLIOGRAPHY}

Alwi, Hasan. 2000. Tata Bahasa Baku

Bahasa Indonesia. Jakarta: Balai Pustaka

Badudu, J.S. 1976. Morfologi. Bandung: Unpublished Collection of Articles

1991. Buku Panduan Penulisan Tata Bahasa Bahasa Indonesia. Jakarta: Pusat Pembinaan dan Pengembangan Bahasa Depdikbud RI.

Berg, Rene Van den. 1989. A Grammar of the Muna Language. Leiden: Summer Institute of Linguistics.

Bloomfield, Leonard. 1973. Language (cetakan keduabelas dari tahun 1933). London: George Allen and Unwin Ltd.

Frank, Marcella. 1972. Modern English. New Jersey: Prentice-Hall. Inc.

Jacobs, Roderick A. 1993. English Syntax, A Grammar for English language Professionals. Oxford: Oxford University Press

Kridalaksana, Harimurti. 1984. Kamus Linguistik. Jakarta: PT. Gramedia

Nida, Eugene A. 1962. Morphology, The Descriptive Analysis of Words. USA: The University of Michigan Press.
Parera, Jos Daniel. 1994. Morfologi Bahasa. Jakarta: PT. Gramedia Pustaka Utama

Quirk, Randolph. 1989. A Grammar of Contemporary English. London: Longman Group Ltd.

Ramlan. 1997. Morfologi, Suatu Tinjauan Deskriptif. Yogyakarta: C.V. Karyono

Samsuri. 1994. Analisis Bahasa. Jakarta: Erlangga

Simatupang, M.D.S. 1983. Reduplikasi Morfemis Bahasa Indonesia. Jakarta: Penerbit Djambatan

Verhaar, J.W.M. 1999. Asas-Asas Linguistik. Yogyakarta: Gadjah Mada University Press

Yatim, Nurdin. 1981. Bahasa Wuna. Jakarta: Pusat Pembinaan dan Pengembangan Bahasa. 